\title{
The contextual search in the landscape space of the school and manor building
}

\author{
Lolita Hercoga, Aija Ziemeḷniece, Latvia University of Agriculture
}

\begin{abstract}
The research deals with the adaptation of the historic manor parks to the needs of schools. In the past hundred years since the founding of schools in the old manor palaces or the lords' houses, a new functional load is brought not only into the historic buildings but also in the old manor park. Most often it is attributable to destroying of the compositional structure of the park, creating a new path network, areas, and individual elements that are not subordinated to the historical sight lines and the structure of the landscape space. This includes important criteria not to lose the scale of the historic parks and the conformity of the stylistic trends of the 18th and 19th centuries. During the last hundred years, only some of the manor parks have undergone the landscape study and development of the documentation but due to the lack of funding the project is not implemented. This has contributed to the creation of separate zones in the manor parks with a random character, which further adds to the lack of professional expertise in the maintenance of the park. A large part of the work to be done will fall on the shoulders of the local government or private owners. Considering the statistics that the number of schools in rural areas runs low, it is possible that the historical legacy comes into the hands of conscious owners, who will devote considerable efforts in the maintenance of the old parks.
\end{abstract}

Keywords: historic manor parks, landscape space, criteria, compositional structure

Introduction

From the 1920s, when the political authorities in Latvia changed, the significance of the manor building ensembles has also changed. Manor buildings and parks have acquired a new function, which has contributed to their use nowadays. With activation of the lifestyle and the needs of the society, it is readable in different innovations in the neighborhood of the manor palace and the area of the park. The changes necessary for the use of modern parks can be observed in the parks in Latvia, in neighboring countries, and in Western Europe [6]. In a number of places, the new elements fully complement the historic building but they often bring disproportion, not respecting the cultural and historical context of the place both stylistically and in terms of location. Although, over time there came functions that facilitate the use and management of the area there is still serious work to be carried out in order to find a balance between preservation of the cultural and historic heritage and innovations of the modern technologies.

One of the most difficult tasks is to balance the mandatory requirements of the training program of the school as an educational institution with its location in a historic manor building.

The time of the agrarian land reform in Latvia from 1922, provided adaptation of the manor buildings for various uses - for the school, sanatorium, people's house, union, dairy, county parish house, poorhouse [1].

Most often the lord's manor house or the palace was adjusted to the school by changing planning of the school building and extensions to the building. According to the data of the Association of Latvian Palaces and Manors, as of 2009 in the manors of Latvia, there were 109 schools [4]. As of 2009, in the manor centers of the national significance operated 17 manor schools, out of them until 2017, schools still are located in 13 palaces (Beḷava, Dzelzava, Ezere, Jaunmuiža, Laidi, Marinzeja, Naukšēni, Ozolmuiža, Pope, Remte, Vandzene, Vilce, Zalenieki).

The manor buildings and parks form the cultural and natural heritage, which in several places is positioned as a tourist site. It is visited and used by school children, local residents, and visitors. To summarize the above, the research aims to examine the development of the area of the school and the manor ensemble in the process of the preservation of the quality of the park.

The assignments of the research concern the analysis of the territories of the park, evaluating the placement of the school activity zones there, to study each of the zones in detail, analyzing the sight points, the distance of the historic tree groups from the sports areas, understanding the compliance of the scale and proportions in specific park locations.

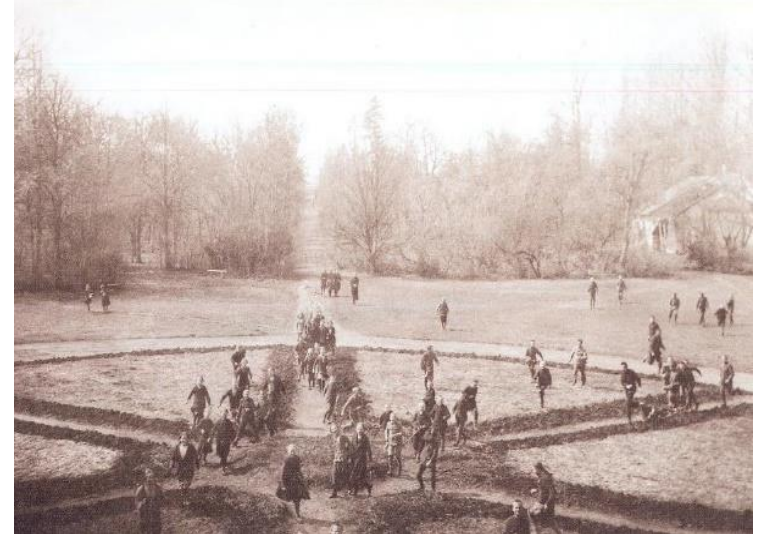

Fig. 1. The park of Svitene Palace. Around 1920 [2] 


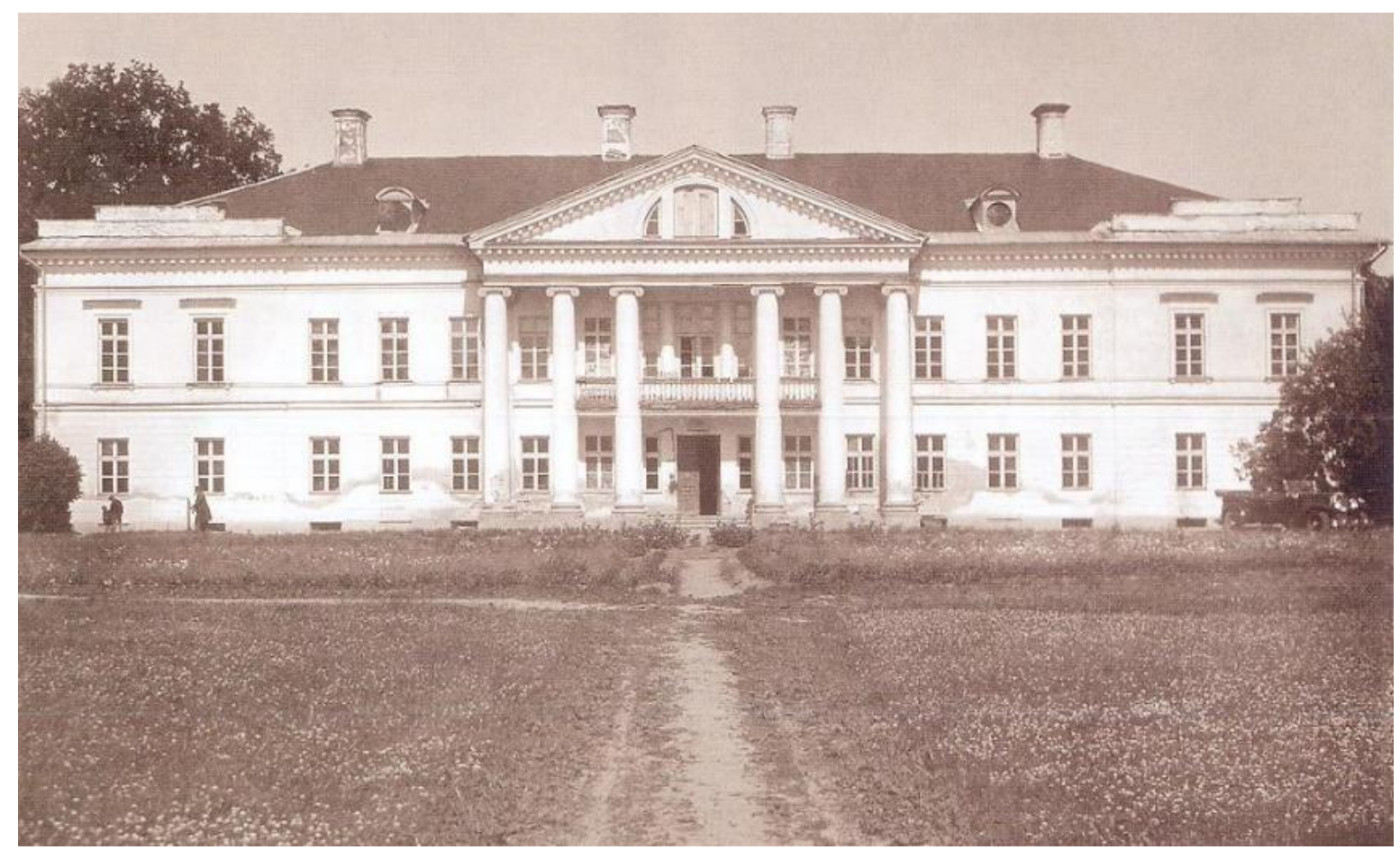

Fig. 2. A view to the glade of the front courtyard from Svitene Palace.1930 [2]

\section{Materials and Methods}

Since the 1920s, the school building in the historic manor building affects not only the buildings but also the park's area, in which sporting areas, green classes, and small summer stages with spectator places are located. Most often, they served as a school-based activity center in parish centers, bringing together locals in a picturesque shady park on summer evenings. It encouraged the village people to meet at feasts and in traditional events, which is especially true in the 1950s - 1980s. The arrival of a new functional load in the park consisted of the development of a new infrastructure - access roads, parking lots, fireplaces, floorboards or asphalted areas for the dance area, summer pavilions, terraces, enclosing plantations, fencing, toilets, storage of waste containers, etc..

The research is based on the comparative method, based on a card materials, photo fixations, architectural and historical research materials, and the exploration of parks in nature. For obtaining the comparative data in the study, in the exploration of the manor parks a ready-made landscape inventory questionnaire is used, which reflects the current state of the landscape space in the manor building and the parks. The landscape inventory questionnaire is structured in four sections: the general data, the visual aesthetic quality of the landscape, education, tourism, and recreation.

The general data include information about the location of the manor, the name of the current school, and the time of its construction in the manor building ensemble. The creation time of the manor park and the park area are fixed.

The visually aesthetic quality of the landscape includes a study on the assessment of the current situation of the elements of the composition forming the structure of the palace and the landscape space of the park, and the assessment of new landscape elements in the context of the cultural history of the site and the modern functional meaning.

Education represents fixed landscape transformation processes resulting from the change of functionality of the lord's house. The schools perform the educational function in the historical building of the manors, in their surrounding areas, and parks.

Tourism and recreation include the cultural and historical heritage that is positioned as a tourist attraction by carrying out surveys, whether the required infrastructure is provided for leisure facilities in the park. It is particularly important to apply it to the recreational attraction of the local population. The survey of the park was carried out from September 2016 until November 2017.

\section{Results and Discussion}

The surveyed schools are located in three Latvian regions: in Kurzeme - six, in Vidzeme five, and in Zemgale - two. In the historic manor building, schools of a different level of education operate - elementary schools, primary schools, the social adjustment institution, the commercial and craft high school. The first schools in the manors 


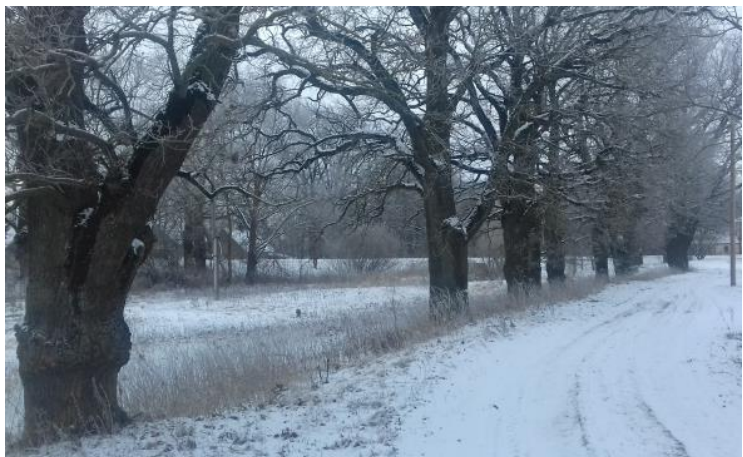

Fig. 3. The oak alley to the farmhouse [photo by A. Ziemelniece, 2017]

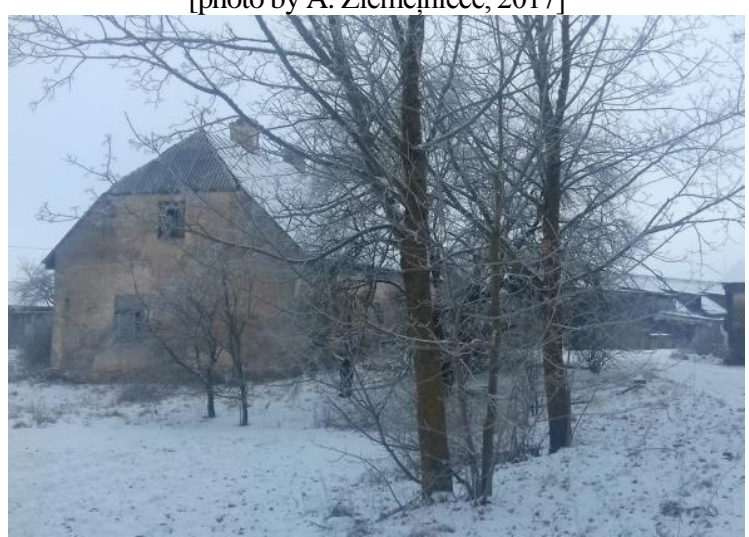

Fig. 4. The farmhouse of the Manor [photo by A. Ziemelniece, 2017]

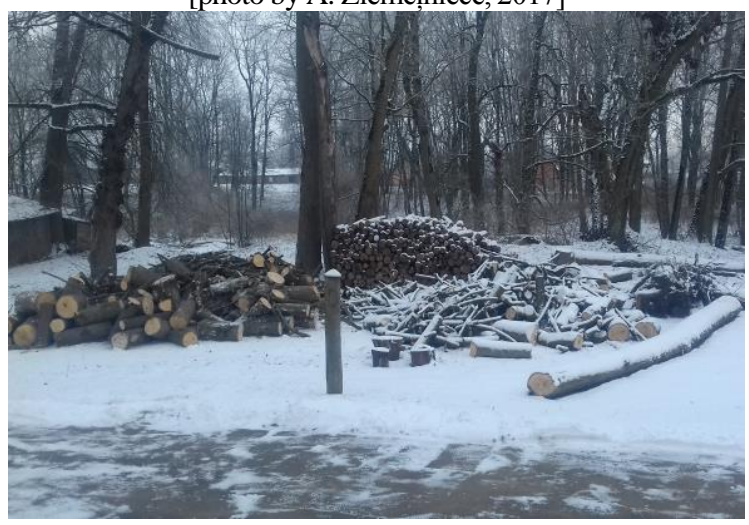

Fig. 5. View from the manorhouse to the park

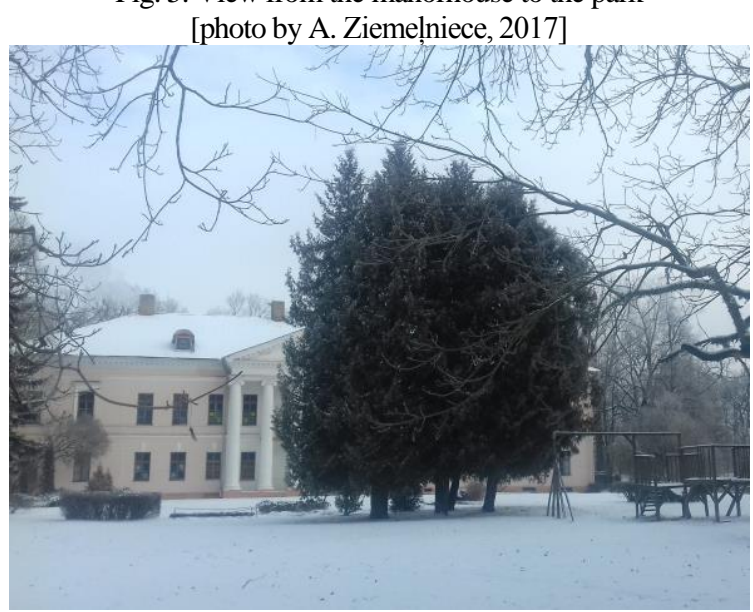

Fig. 6.View to the manorhouse [photo by A. Ziemeḷniece, 2017] date back to the $20 \mathrm{~s}$ of the $20^{\text {th }}$ century, when in Latvia the agrarian land reform started, taking away the manor building center and the agricultural land belonging to the German nobility. Most often, the center of the manor was adapted to the needs of the school. A hundred years have passed since the time of the above reform and in many lord's houses schools continue to operate. During this period, the park nearby to the manor building is adjusted to the school sporting area, so bringing in a new feature in the park. This solution is acceptable as in the world experience there is the transformation of a definite space of the park, bringing in an additional functional load. It only requires a careful and thoughtful solution to the scale, position, and the material used, and a random character is not acceptable. The finely polished compositional structure of every historical park is sensitive to unwisely arranged new paths or areas that may affect the compositional integrity of the park. The surveyed manor or school parks are arranged in the $60 \mathrm{~s}-70 \mathrm{~s}$ of the $18^{\text {th }}-19^{\text {th }}$ centuries, and they are older than 150 years, so creating a very strong historical landscape space, visually easy to understand. Studying Latvian manor or school parks, overlaying of the economic activity of the last century is also apparent that is alien to the historical identity of the park. It is most often attributed to the central glade of the front courtyard. Historically, the view of the lord's house from the driveway carried out a representation function. The sight lines were constructed open, without tree plantings in the circle of the front courtyard, so that the lord's manor house could be seen from a distance. Currently, the open view of the palace remains only to three of the surveyed sites. This is explained by the Latvian Government's decision made in the 20 s of the $20^{\text {th }}$ century, which intended to hide the heritage carried by the Baltic German culture. Especially quickly this was done with the disruption of the main sight line for the front courtyard, planting a dense line of thujas, spruces or oaks in front of the palace. A vivid example is Svitene Palace (the school building), Kaucminde Palace (the household school), etc. $[2 ; 3]$. The recovery of the historical form of the lord's house or the front courtyard of the palace from 1990 is progressing very slowly. Mostly, this is true for trees, planted in the center of the driveway circle. This is due to the emotional surge, as it is painful to cut almost 100 years old trees in the center of the front courtyard. It is similar to the groups of ornamental plantings not matching the scale and flower beds, created in decades but the form creation of the flower beds violates the common architectural stylistics of the building. The back facade of the lord's house was typically 


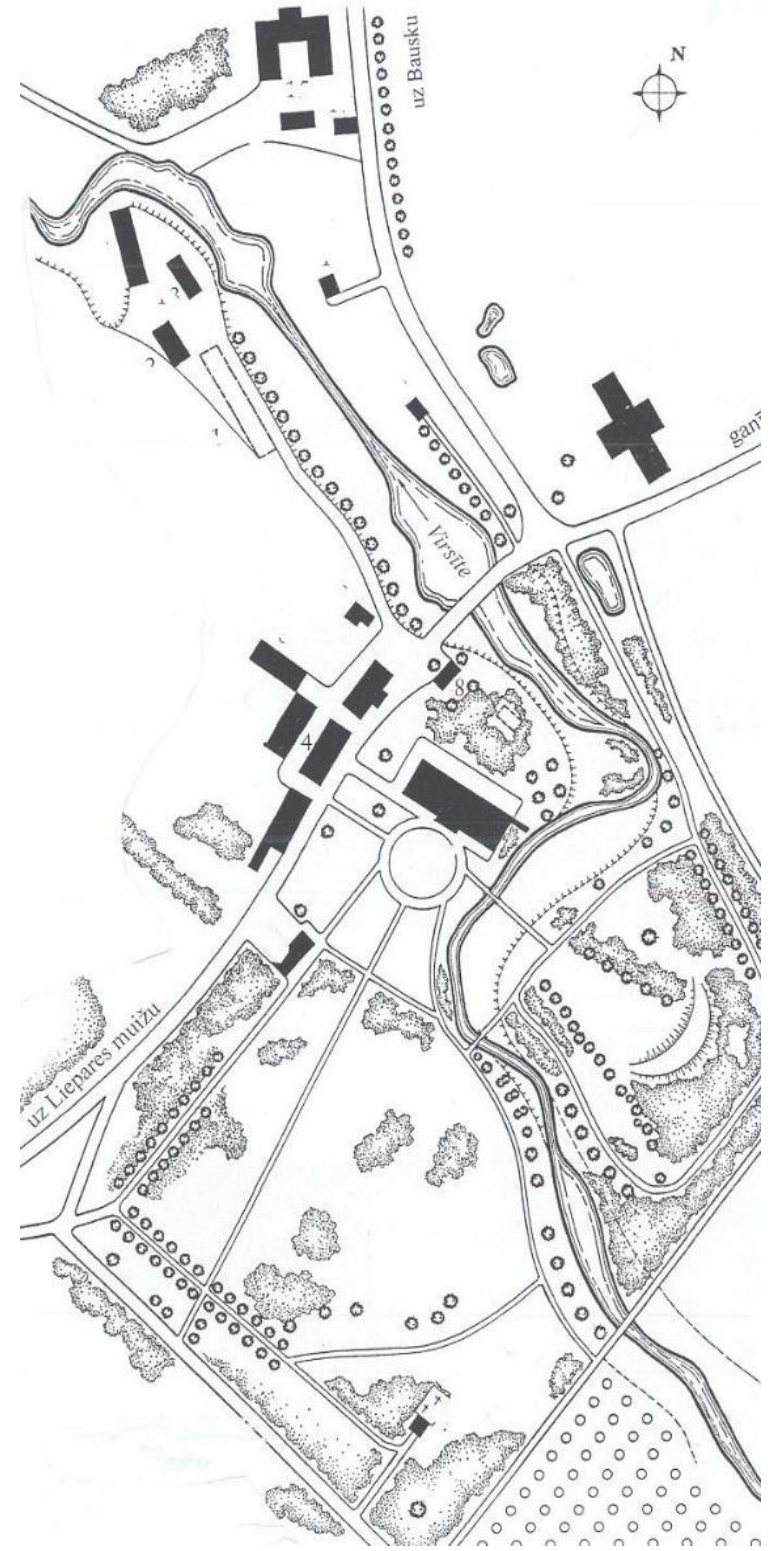

Fig. 7. The park of Svitene Palace. Around 1920 [2]

made more intimate and it was associated with the part of the park in the center of which a glade was located on the longitudinal axis. Closer and further groups of trees, soliters, water elements, architecture in small forms (for instance, a vase, a pavilion), as well as a small area of activities could be viewed. Four palaces surveyed in the course of the research open up an expressive view of the park, which is enriched by different dimensions of the sight lines of the park and the dendrological peculiarities of the groups of trees.

From Laidu Palace and the manor palaces of Vilce, the sight lines lead to well-exposed sight lines, which include separate groups of the historical tree plantations. The glade of Naukšēni Manor includes the natural landscape of the river Rūja. The lord's house of Pope Manor forms a picturesque link of the central glade with the pond, behind which there is the old hunters' lodge.
Only the mystery of the central glade is broken by the school sporting area, obsolete, bright metal gym elements, industrial standard fencing, new plantations disproportionate to the scale, closely built a high rise residential building, a shed for wood. In the late autumn, in the park of Remte Manor, the park pavilion is noticeable in the far sight line.

A school territory is an important place for patriotic upbringing. Therefore, in front of several lord's houses after 1990 memorial marks are placed in the deportation places or for the occupation victims (Remte Palace). This action has initiated conversion of the most picturesque manor ensemble sites to a political struggle "altar". After the survey of the above parks, memorial sites are arranged in four parks.

Svitene Palace with the park can be mentioned as a bright example of the adjustment of the historic lord's house and the park (the primary school by 2016). The park as a beautiful one is already mentioned in 1846 during the visit of J. Doering. Since then, the trees have been grown older. The park compositionally consists of several landscape spaces. Until the start of the $20^{\text {th }}$ century, the front courtyard historically formed a widely transparent sight line, where from distant sight lines the palace was visible [2]. Currently, the southern part of the sight line reminds a city-type square. At the western edge of the sight line near the road the gardener's house. Today, the mentioned sight line is lost. Researching the old tree planting sites, it must be concluded that there had been walking paths along both river banks with romantic sight lines. In the southern part, the sight line is concluded by a transverse axis, which is formed by a linden alley, which leads to the crypt of the barons.

On the southeastern side of the glade, there are the scenic banks of the river Viesite, which are joined by one small bridge opposite the palace. The left bank of the river slope at the palace forms a link to the park's part, that contrary to the wide and light glade of the front courtyard forms a pleasant shading during the scorching summer days. Opposite the path - the historical place of the glade where for the school needs a sporting area with asphalt cover is arranged.

The compositional structure of Svitene Park is changed not only by the time of the political games but also by the demands of the Soviet time according to the rational disposition of the engineering structures. This is attributable to the position of the water tower in the area of the front courtyard, not respecting the historic values but emphasizing technical issues of household nature as the main ones. 


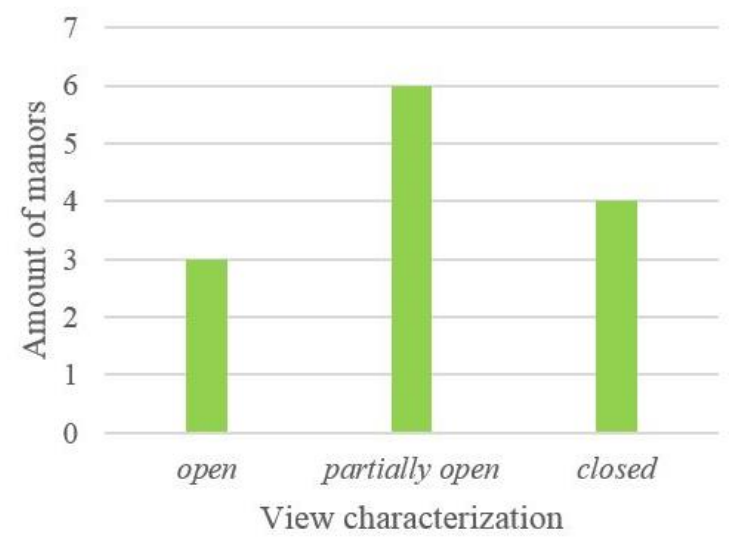

Fig. 8. The description of the representative view of the manor palace [created by the author]

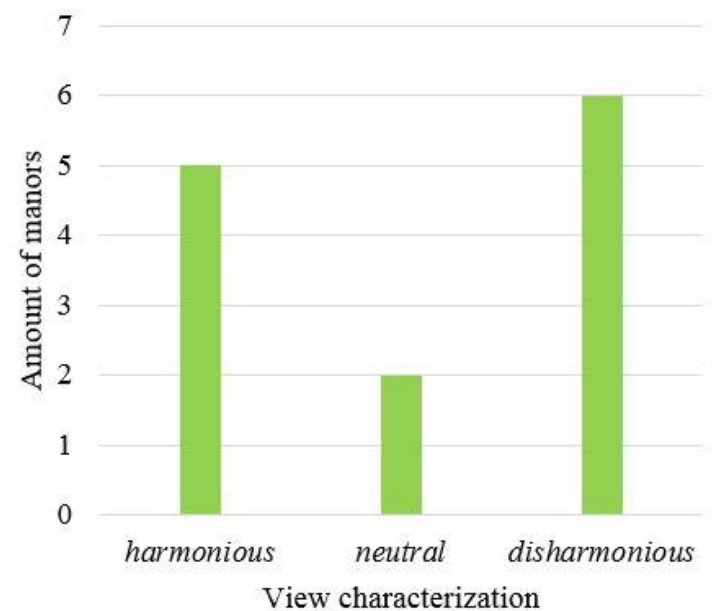

Fig. 9.The assessment of the sight to the central glade of the park [created by the author]

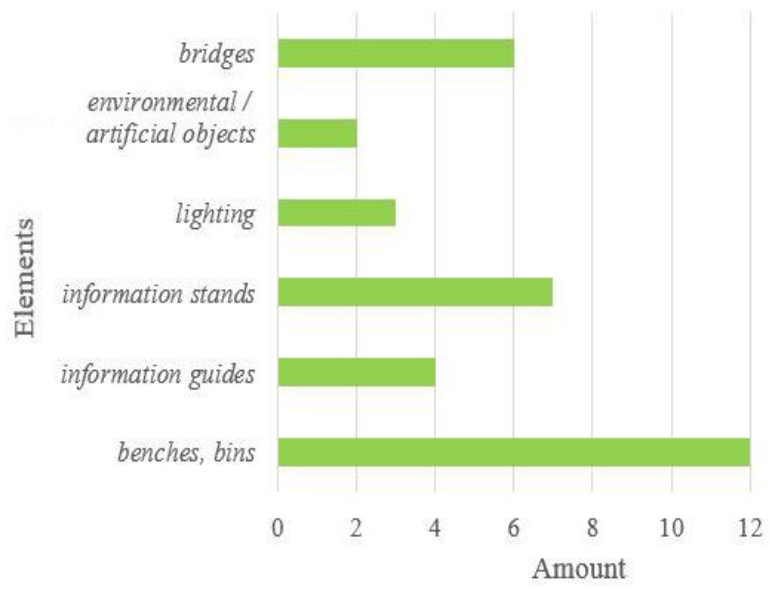

Fig. 10. The new facility elements of the park [created by the author]

The expressiveness of the sight point in the areas of manor parks is affected by the overall nature of the construction of the park:

- The landscape space of the park and the glades are formed by groups of trees and bushes;

- The groups of trees and bushes do not constitute a distinct landscape space;

- The park is transparent, its structure is primarily determined by the trees.
Of the surveyed parks, in eight parks the structure of the landscape space of the park is readable which is formed by glades and plantings. Due to a wrong management, four parks are too groomed or have become dull, as sight lines with evenly correct trunk rhythm of the trees have developed in the park.

In each of the parks included in the research, any of the elements of water are met (a river, pond, lake, spring, ditch, wetlands, an island) which brings the intrigue and mystery in the park. In ten of the surveyed parks, the land surface is flat or moderately undulated, therefore the importance of the plantings in the creation of the landscape space of the park is growing.

From the historic plantation forms, in eleven of the surveyed manors alleys are located. Circular plantations (around the former arbor) are identified in three parks. It should be noted that the topographic measurement and the inventory of the woody plants could reveal yet so far unidentified circular or arc-type plantations. Assessing the quality of the new plantations of the parks, it is concluded that the plantations appropriate to the scale of the site are met - in four parks, partly appropriate quality - in five parks, and an inadequate compositional character - in 5 parks. The protection of the new plantations can be observed in 3 parks.

The small architectural forms are little preserved. Road guidance posts of stone are found - in seven parks, in Ezere Park - foundations of a pavilion have survived. In the park of Remte Manor, a vase podium, torment chamber, grotto, hunting tower, and the pavilion columns can be found. From the visited parks, the small forms of the historic architecture of parks were not found in five of the visited parks.

In the school parks for walks included in the research, both paths and the ground vegetation are used. Six of the surveyed parks have a general path network. A partial path network has remained in four parks but in three parks, the path network does not exist. Considering the compliance of the access road to the palace and the cover of the park's paths with the historic place, in ten manors it is to be assessed as partially adequate. The dominant cover type is asphalt or a concrete pavement.

In the parks, new facility elements are installed benches and garbage bins, signs, billboards, illuminations, environment/art items, small bridges. Only in three parks, the design of new facility elements is judged as appropriate for the historic site, others - of an inadequate quality. The new construction volumes of an economic character - in 12 parks, which have arisen in the post-war years, in terms of the architectural form are of low quality (Fig. 10). 
The new facility elements are fixed for educational activities in the school or the old manor parks - such as benches with Latvian characters in outdoor classes and informative educational elements, such as the Latvian and Latin name of the tree nearby it. For sporting activities, in all the surveyed parks a stadium is built, in 10 parks - gym equipment is placed and in 12 parks-sports playgrounds are installed (for basketball, volleyball, tennis, etc., games). The sporting activity areas are equipped near the lord's house (palace). They can be reached in a very short time, but judged as a degrading element of the cultural landscape. Children's playgrounds are installed in 7 parks behind the manor palace or sometimes next to it. The infrastructure necessary for school activities is focused nearby the palace, the landscape space of the park is less used.

For the promotion of tourism and recreation infrastructure near the schools or the historical palace, informational elements are placed that help the visitor to find new information and navigate in the space. Reference stands were located in 6 parks, in turn, a descriptive planning of the park is located just in 3 parks, informative references - in 5 parks. Near the manor palaces, where the tourist information is located, it refers to the manor ensemble, the palace, the baronial family. A few lines are sometimes found about the parks, although they have the potential to become just as important tourist attractions like the palace, making it possible for tourists to stay longer at the site and to get a wider picture of the manor palace and its surroundings. In the park, the local population is brought together by the stages, found in 7 parks. The campfire site is located in 4 parks but the picnic site - in 8 parks. A bathing place is located in one of the parks.

\section{Conclusions}

The school as an educational institution at a cultural and historical site has a dual benefit to its school youth. This is particularly attributable to the transfer of the historical cognition to the next generations.

The manor building and the structure of the park of the last century has been distant from the historical original form. It contributed to the need for new facilities, subordinated to the interests of the schools, local residents, and tourists.

The surveyed center territories of the manors have a potential to evolve in accordance with the site's identity and implementation of complex solutions, raising the cultural quality of the cultural and historical site, which is enhanced by the start of the volumes of restoration work both for buildings and the park area.

The use of the area of the parks for the school needs most often is limited to the stadium, playground, and gym area. The park has a much wider range of opportunities that can be used by the school - to learn about plants, animals, history, art (color transitions, proportions), to draw and paint, listen to the birds, observe natural phenomena, and more. By restoring the historic manor garden, there is the opportunity to provide school children with healthy fruits. The Eco-school program is applicable to the placement of schools in manor buildings.

Estonia has a successful example where horses are currently kept in the stables of Ruila Manor, and riding classes are included in the school curriculum (an exhibition of schools in Estonian manors). In Estonia, a program for the restoration of manor schools has been implemented. In the ten years (2004-2015), 14 schools have been restored.

The rebirth of historical territories is largely due to the human activity or inactivity and natural processes. The municipality, the Ministry of Education and Science, and the Inspection for the Protection of Cultural Monuments are responsible for the development of the school territory in the historic manor houses.

\section{References}

1. Janelis, I. M. Latvijas muižu dārzi un parki. Rīga: Neputns, 2010.

2. Lancmanis I. Svitenes muiža = Schwitten; Bērsteles muiža = Gross-Bersteln. Rundāle: Rundāles pils muzejs, 2003. $85 \mathrm{lpp}$.

3. Lancmanis I. Kaucmindes muiža = Kautzemünde. Rīga: Rundāles pils muzejs, 1999. 52 lpp.

4. LPMA - Skolas pilīs un muižās [online] Latvijas piḷu un muižu asociācija (LPMA) sadarbībā ar www.google.com/maps [cited 12.11.2017] www.google.com/maps/d/viewer?mid=1qAH_hqDvfswEhqCrl0N7tnl ZRU\&hl=en_US\&ll=56.91389886596841\%2C24.543499500000053\&Z=17

5. Valsts kultūras pieminekḷu aizsardzības inspekcijas Pieminekḷu saraksts [online 12.11.2017] www.mantojums.lv /lv/piemineklu-saraksts/

6. Rubene, S., Lāčauniece, I. New structural elements and activities in historical gardens and parks. Scientific Journal of Latvia University of Agriculture. Landscape Architecture and Art. Jelgava: LLU, 2016, Vol. 5, No 5, p. 14-24. 
INFORMATION ABOUT AUTHORS:

Lolita Hercoga, Landscape Architect in Ltd. "Veido vidi". Master student (since 2016) in Latvia University of Agriculture, Department of Landscape Architecture and Planning. E-mail: hercoga.lolita@gmail.com Aija Ziemelniece, Dr.arch., Professor at the Faculty of Environment and Civil Engineering, Department of Landscape Architecture and Planning of the Latvia University of Agriculture, 22 Liela iela, Jelgava, Latvia, LV-3001. E-mail: aija@k-projekts.lv

Kopsavilkums. Pētījums aplūko vēsturisko muižu parku pielāgošanas iespēju skolu vajadzībām. Pēdējos simts gadus kopš skolu dibināšanas buma vecajās muižu pilīs vai kungu mājās, ir ienesta jauna funkcionālā slodze ne tikai vēsturiskajām ēkām, bet arī vecajam muižas parkam. Visbiežāk tas ir attiecināms uz parka kompozicionālās struktūras izjaukšanu, izvietojot jaunu celiņu tīklu, laukumus un atsevišşus elementus, kas nav pakārtoti vēsturiskajām skatu līnijām un ainavtelpas uzbūvei un ietver svarīgus kritērijus, lai nepazaudētu vēsturisko parku mērogu un atbilstību 18./19. gs. stilistikas tendencēm. Pēdējo simts gadu laikā tikai dažiem muižu parkiem ir veikta ainaviskā izpēte un dokumentācijas izstrāde, taču finansējuma trūkuma dēl projekts nav realizēts. Tas ir veicinājis muižu parkos veidoties atseviškāanm zonām ar nejaušǐbas raksturu, kuru tālāk papildina profesionalitātes trūkums parku uzturēšanā. Liela daḷa no perspektīvē darāmā darba gulsies uz pašvaldības vai privātīpašnieka pleciem. Ievērtējot statistiku, ka skolu skaits lauku teritorijās iet mazumā, iespējams, ka vēsturiskais mantojums nonāk apzin̄̄gu īpašnieku rokās, kas veltīs ne mazums pūlu veco parku uzturēšanā.

No 20. gadsimta divdesmitajiem gadiem, mainoties Latvijā politiskajām varām, līizi ir mainījusies arī muižu apbūves ansambḷu nozīme. Muižu ēkas un parki ir ieguvuši jaunu funkciju, kas veicinājis to izmantošanu mūsdienās. Aktivizējoties dzīvesveidam un sabiedrības vajadzībām, tas ir nolasāms dažādos jauninājumos muižas pils apkārtnē un parka teritorijā. Pārmainasas, kas nepieciešamas mūsdien̄̄gai parku izmantošanai, novērojamas parkos Latvijā, kaimiņvalstīs un Rietumeiropā. Daudzviet jaunie elementi labi papildina vēsturisko apbūvi, bet nereti tie ienes disproporciju, nerespektējot vietas kultūrvēsturisko kontekstu gan stilistiski, gan novietojuma ziṇā. Lai arī laika gaitā klāt nākušās funkcijas veicina teritoriju izmantošanu un apsaimniekošanu, taču ir vēl nopietns darbs veicams, lai rastu līdzsvaru starp kultūrvēsturiskā mantojuma saglabāšanu un mūsdienu tehnolog̣iju jauninājumiem.

Kā viens no grūtākajiem uzdevumiem ir sabalansēt skolas kā izglìî̄ibas iestādes obligātās mācību programmas prasības ar to novietojumu vēsturiskā muižas ēkā. Agrārās zemes reformas laiks Latvijā no 1922. gada noteica muižu apbūves ansambḷu pielāgošanu dažāda rakstura izmantošanai - skolai, sanatorijai, tautas namam, biedrībai, pienotavai, pagastmājai, nabagmājai. Visbiežāk muižu kungu māja vai pils tika pielāgota skolai, mainot ēkas plānojumu un veidojot piebūves. Saskan̄ā ar Latvijas Piḷu un muižu asociācijas datiem uz 2009. gadu Latvijas muižās pastāvēja 109 skolas. Uz 2009. gadu valsts nozīmes muižu centros darbojās 17 skolas, no tām līdz 2017. gadam skolas vēl izvietojas 13 pilīs (Beḷava, Dzelzava, Ezere, Jaunmuiža, Laidi, Marinzeja, Naukšēni, Ozolmuiža, Pope, Remte, Vandzene, Vilce, Zaļenieki). Muižu ēkas un parki veido kultūras un dabas mantojumu, ko vairākās vietās pozicionē arī kā tūrisma objektu. To apmeklē un izmanto skolēni un vietējie iedzīvotāji. 